\title{
Development Rime Syar'i Business \& Administration Management System with Rapid Application Development Method
}

\author{
Melati \\ Software Engineering Technology, \\ Agriculture Polytechnic of \\ Samarinda, 75242, Indonesia \\ melatimi2399@gmail.com
}

\author{
Eko Junirianto (1) \\ Software Engineering Technology, \\ Agriculture Polytechnic of \\ Samarinda, 75242, Indonesia \\ eko@politanisamarinda.ac.id
}

\author{
Ida Maratul Khamidah (i) \\ Software Engineering Technology, \\ Agriculture Polytechnic of \\ Samarinda, 75242, Indonesia \\ idamaratul@gmail.com
}

Submitted: 2021-10-04; Revised: 2021-10-05; Accepted: 2022-02-23; Published: 2022-03-01

\begin{abstract}
This research aims to produce an administrative information system design to increase accuracy in data processing and the ability to provide faster information for a business and increase the accuracy of service to consumers. This study also aims to identify information system problems on the system running on Rime Syar'i business and produce a Webbased administrative information application program that includes administrative transactions to produce transaction reports and reports that are needed to facilitate business management. Rime Syar'i. The conclusion obtained from this research is that using a web-based information system, can minimize errors in data processing, increase the effectiveness and efficiency of Rime Syar'i's business work in a better direction, and ease in making reports.
\end{abstract}

Keywords - Information System, Management, Business, Administration

\section{INTRODUCTION}

The business needs of Muslim women began to increase among Muslim women. This happens because the need for Muslim clothing is increasing rapidly, in addition to certain events such as during the month of Ramadan ahead of Eid al-Fitr and Eid al-Adha as well as many women wearing Muslim clothes and headscarves to cover their genitals and Muslim fashion is increasingly fashionable.

A hijab is no longer just a head covering. But the hijab has become a must in Islam and creates a fashionable and attractive appearance. This can be seen from the number of hijab sellers who fill almost all shopping centers. Many books are deliberately written and printed to provide guidelines and variations on the use of the hijab so that more and more women and young women finally have to wear a headscarf or headscarf as a complement to their appearance. Therefore, Rime Syar'i is one of the businesses that produce Muslim clothing that is designed according to the needs of its consumers. Namely with a fashionable design, affordable prices, and quality. Marketing is one of the most important factors in the management of a business because marketing will directly affect the smooth running of the business in achieving its goals. Product marketing is now available in various forms. Apart from writing and images, now with technological advances, many product marketing is also using an android-based platform (Sari et al., 2021)

Rime Syar'i is currently still using manual data collection, besides that researchers also find many shortcomings in the application of computerized technology because it is not systemized, the problems found in this case are processing information from data collection of goods and product sales carried out manually in books and irregularly. Whereas information processing is an activity that affects business operations because it can help the owner/leader in making decisions. With this background, it is proposed to renew the old system into a new administrative information system with Web-based technology, with the system being able to facilitate the company in providing information so that activity decisions in a business can run according to company conditions and are more easily handled. access and use.

Technology, which since the early 70s began to be developed, is currently experiencing very rapid development. Technological capabilities have now been able to solve various problems that are closely related to technology, so for the progress of a company to expand the market, a system is needed that can facilitate companies in providing information to consumers about their products and things related to buying and selling transactions. In addition, a company needs a system that can be accessed by many people anytime and anywhere as long as it can be connected to the internet network.

The formulation is based on the background that has been described, how to design and build a web-based administrative information system for processing information from data collection and product sales.

The limitations of the problem are as follows, namely, the information system is built on a web-based basis with the Laravel framework, the data presented is based on data from the Rime Syar'i Sales Application, this administrative information system will only be adapted to the Rime Syar'i product sales application.

The purpose of this application is to design and build an administrative information system at Rime Syar'i's business so that the inputs and outputs obtained are under 
the needs of the business and can help manage Rime Syar'i's business activities.

The expected results with the design of this information system are expected to facilitate Rime Syar'i's business in managing sales and stock administration reports to be more organized and more practical so that the results obtained can assist further decisions in the business.

Based on these problems, the researchers decided to take the title "Web-Based Rime Syar'I Business Management Administration Information System" in writing this research.

\section{LITERATURE REVIEW}

\section{A. Study of Literature}

Some of the literature used as a guide and reference in this thesis include:

The research was conducted by (Saleh et al., 2018) from the Muslim University of Indonesia entitled "Designing a Sales Administration Management Information System at a Web-Based Outdoor Lintang Store". In this study, the Administrative Management Information System helps the marketing and sales process, as well as handles sales transaction reporting, detailed reporting of sales transactions for a certain period.

The research was conducted by (Ilmiah et al., 2016) from the University of Muhammadiyah Surakarta, with the title "Information System for Motor Vehicle Service Administration and Web-Based Spare Part Catalog with Single Application (SPA) Technology." This workshop administration application system in its role helps activities Workshop operations include:

1. Customer service data collection will be easier and stored securely.

2. Making and printing invoices will be easier and faster.

3. Making workshop income reports easy and fast.

The research was conducted by (Akbar, 2017) from UNISNU Jepara entitled "Design of Hotel Administration Information System with Extreme Programming Method". This research focuses on developing a hotel administration information system that facilitates the recording of hotel operations which includes room reservations, registration/check-in, to the guest check-out process. The development of this system will use the Extreme Programming method which is one of the Agile Methodology-based SI Development Methods. The application of the extreme programming method for the development of hotel administration information systems is quite appropriate to the needs because clients can be actively involved in system development and can also respond to changes that may occur in terms of client needs.

The research was conducted by (Fibriyanti et al., 2020) from the Faculty of Economics, Lamongan Islamic University entitled "A Web-Based Marketing Management Administration System for Fishermen's Joint Business Group Partners (KUBE) in Kranji Village, Paciran District, Lamongan Regency". Training related to the creation of promotional websites, administrative systems, and marketing management is a very important aspect and very useful for participants in the village of Kranji they really hope that technological knowledge will not be left behind compared to the districts in the vicinity for the village community.

This research was conducted by (Syukron et al., 2020) from Bina University, entitled "Website-Based Management Information System of Orphanage Financial Administration", finance and also makes it easier to get information.

\section{B. Information Systems}

An information system is a system within an organization that brings together the daily transaction processing needs that support the managerial functions of the organization's operations with the strategic activities of an organization to be able to provide certain outside parties with the necessary reports.

Information systems are several components that are interconnected with each other and work together harmoniously between computers and users in managing changes in data into meaningful and useful information to support decision making, coordination, and control (Alhogbi, 2017).

\section{Management Information System}

"SIM (management information system) is a computer-based system, another network that can provide information for several users, to support management functions and decision-making functions".

\section{Understanding Administration}

The goal to be achieved through administrative activities is to apply work abilities and skills so that goals are achieved effectively and efficiently through rational action. Goals effectively and efficiently through rational action can be realized if there is a realistic and truly precise, logical, and workable plan (Marliani \& Si, 2016). Rapid Application Development (RAD) method

Rapid Application Development (RAD) is a software development process model that is incremental, especially for short processing times. The RAD model is an adaptation of the high-speed version of the waterfall model by using the waterfall model for the development of each software component, (Junirianto \& Kurniadin, 2020).

\section{F.UML}

According to (Kusuma \& Prasetya, 2017). Unified Modeling Language (UML) is an architectural system that runs in OOAD (Object Oriented Analysis Design) with a consistent language for determining, visualizing, constructing, and documenting artifacts (pieces of information used or generated in a software engineering process, can be in the form of models). , description, or software contained in the software system.

\section{RESEARCH METHODS}

The research procedure of this paper starts from identification, literature study, designing system, building 
system, testing system, and if there is a bug fixing system is needed. The research procedure can be seen in picture 1. This research procedure is shown as a flow chart diagram.

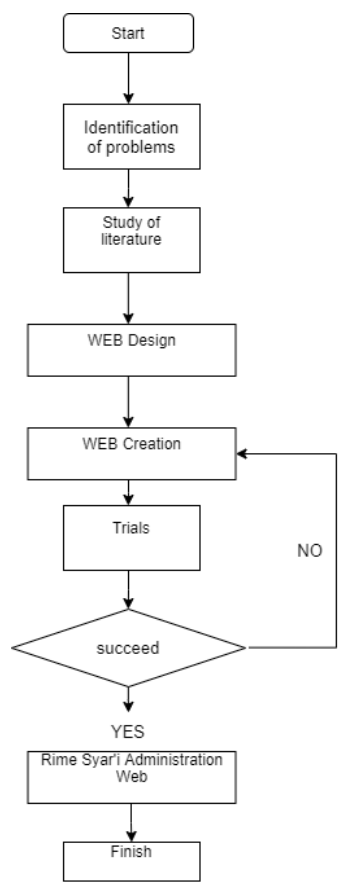

Picture 1. Research Procedure

\section{A. Model Rapid Application Development (RAD)}

The method used in system development is Rapid Application Development. This method can be seen in picture 2 .

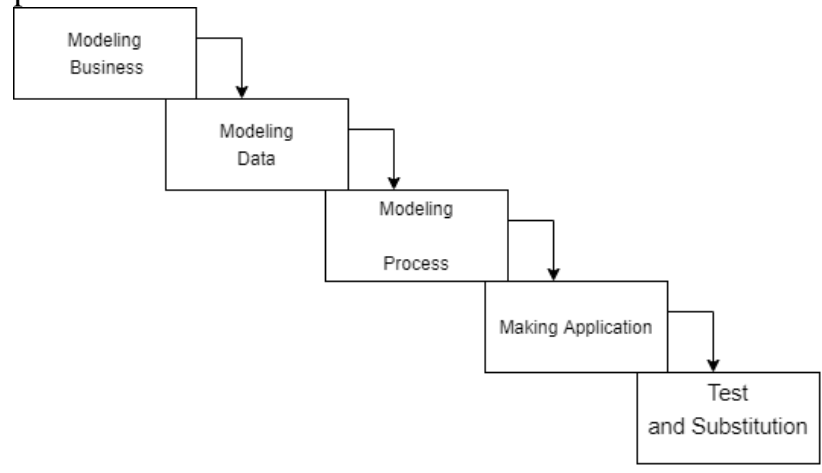

Picture 2. RAD Method

B. Sales System Design

1. Use Case Diagrams

Use Case Diagram describes what will be done by the system that will be built and who will interact with the system. The following is the design of a Use Case Diagram of a Web-Based Rime Syar'i Business Management Information System, use case can be seen in picture 3 .

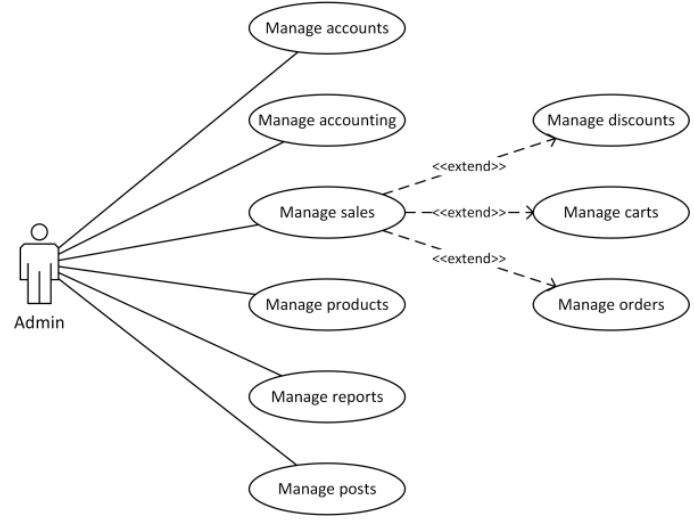

Picture 3. Use Case Diagrams

\section{RESULT AND DISCUSSION}

The results of making this application are as follows: The results of making the WEB-based Rime Syar'i business management information system application with the Rapid Application Development method are as follows.

\section{A. Home View}

The home page displays sales charts and reports to the Rime. Syar'I administration based on the data that has been entered, it can be seen in Picture 5.
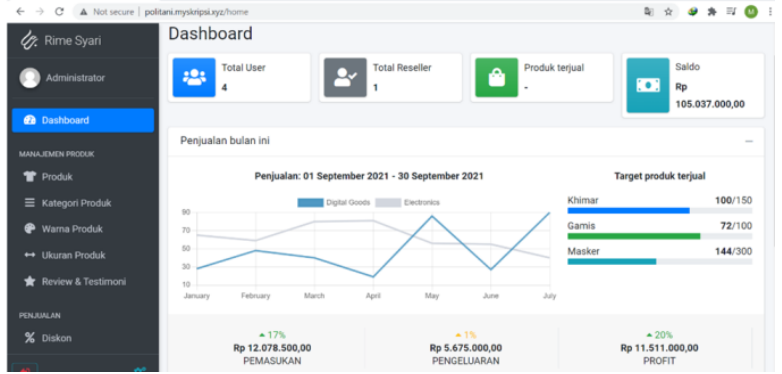

Picture 5. Home View

\section{B. Admin Data Display}

This admin page displays admin data that has been registered and has logged into the system, it can be seen in picture 6 .

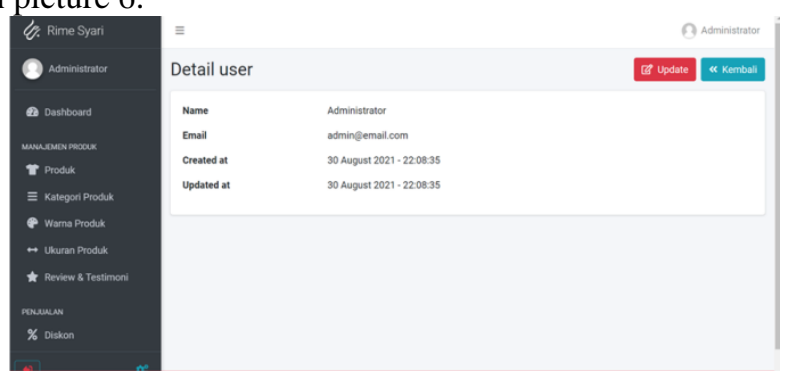

Picture 6. Admin Data Display

\section{Product Data Display}

On this page is a data display for adding new product data and uploading product photos, it can be seen on picture 7 . 


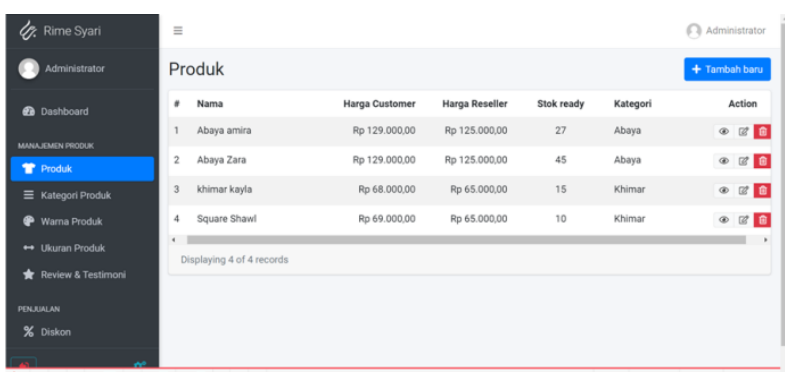

Picture 7. Product Data Display

\section{Product Category Data Display}

On this page is a display for adding new product categories, which can be seen in picture 8 .

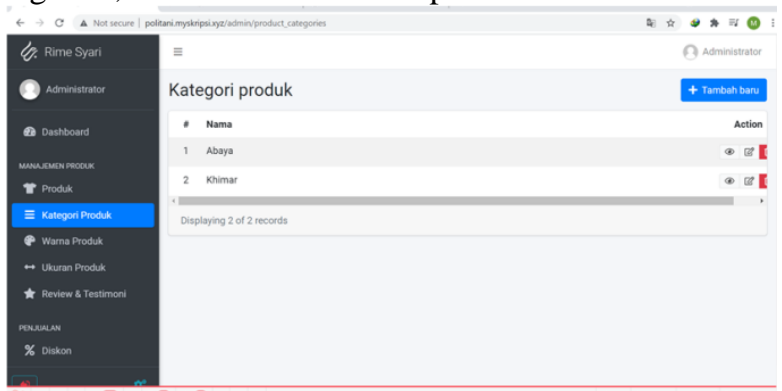

Picture 8. Product Category Data Display

\section{E. Product Color Data Display}

On this page is a display for adding product color data, it can be seen in picture 9 .

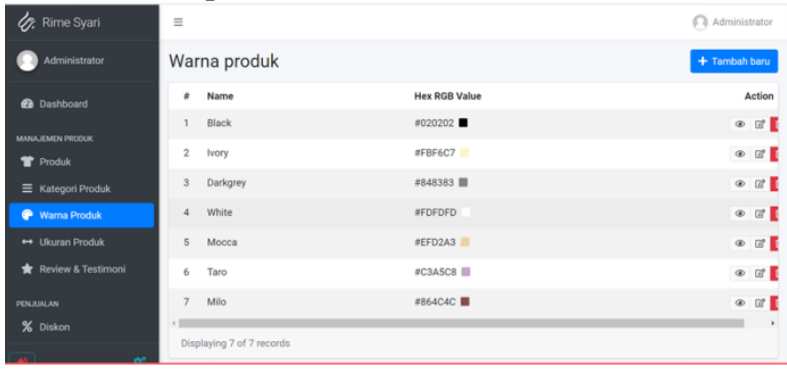

Picture 9. Product Color Data Display

\section{F. Product Size Data Display}

This page is a display to add product size data to be entered, it can be seen in picture 10 .

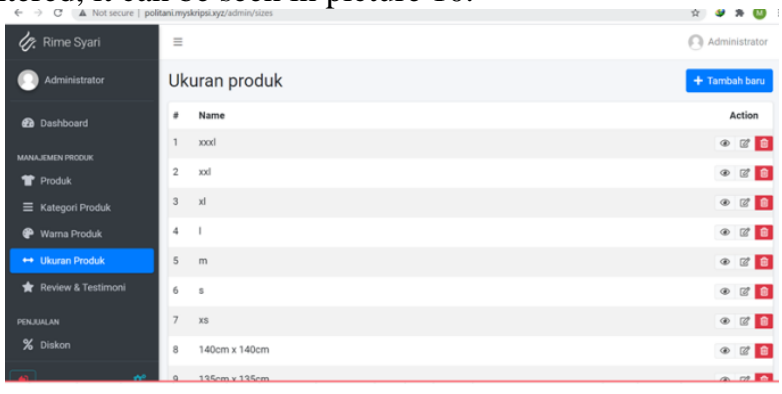

Picture 10. Product Size Data Display

\section{G. Display Reviews and Testimonials}

This page is a display to display review data and testimonials from users who have successfully purchased products on the Rime Syar'I android application, which can be seen in picture 11 .

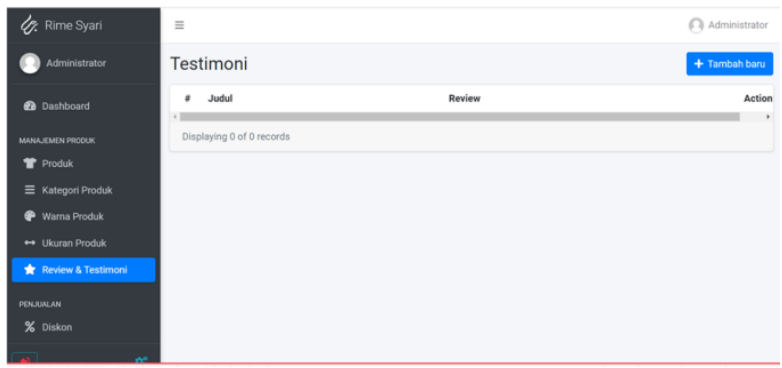

Picture 11. Display Reviews and Testimonials

\section{H. Discount Data Display}

This page is a display to add discount data for products or discount vouchers, which can be seen in picture 12 .

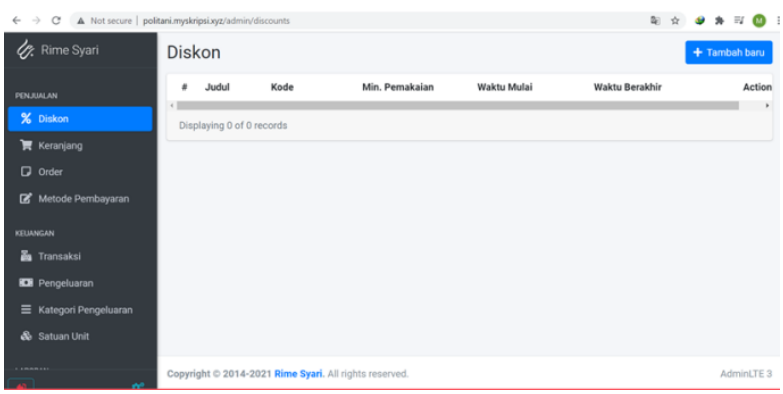

Picture 12. Discount Data Display

\section{Cart Data Display}

This page is a display to display the basket data entered by the user, it can be seen in picture 13 .

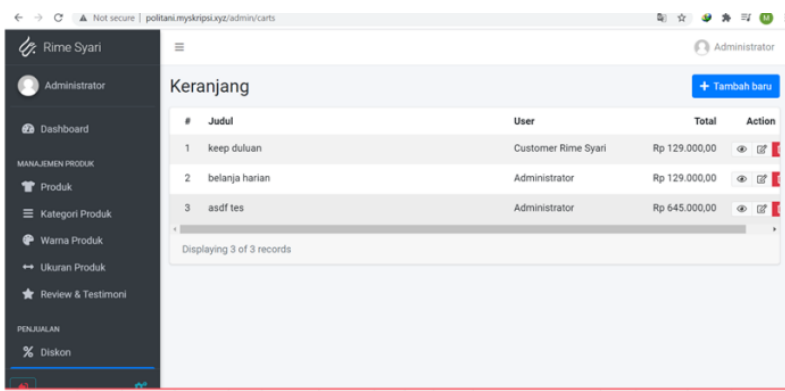

Picture 13. Cart Data Display

\section{J. Order Data Display}

This page is a data display for displaying, adding, and deleting user order data, it can be seen in picture 14 . 


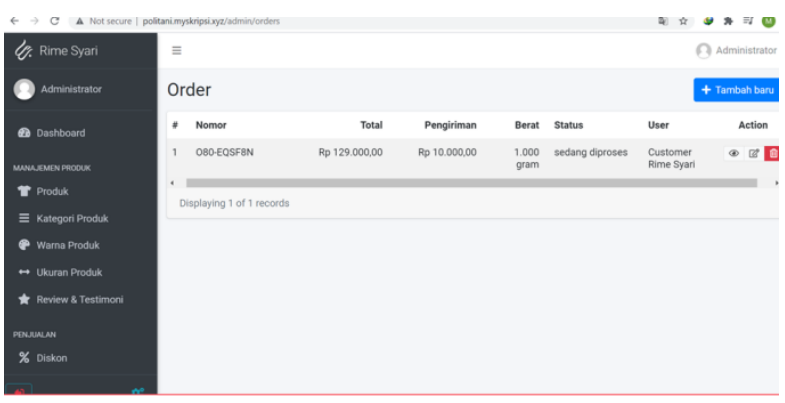

Picture 14. Order Data Display

\section{K. Payment Method Display}

This page is a data display for providing payment methods on the Rime Syar'I sales application, it can be seen in picture 15 .

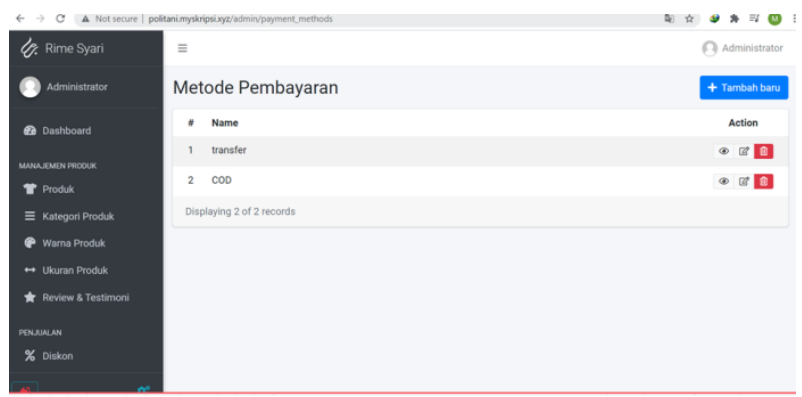

Picture 15. Payment Method Display

\section{Transaction Data Display}

This page is a display to display transaction data that enters the Rime Syar'i android application, it can be seen in picture 16.

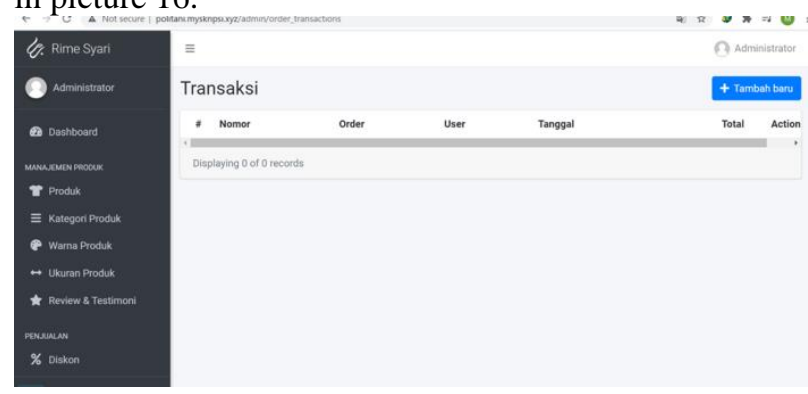

Picture 16. Transaction Data Display

\section{Expenditure Data Display}

This page is a display to display Rime. syar'i expenditure data and can add product stock according to the selected category it will automatically add product stock, as can be seen in picture 17 .

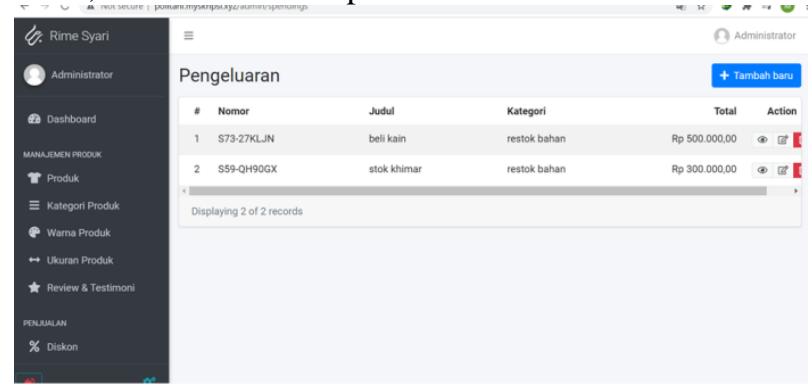

Picture 17. Expenditure Data Display

\section{N. Profit and Loss Data Display}

This page is a display for displaying a sales profit and loss report, it can be seen on picture 18 .

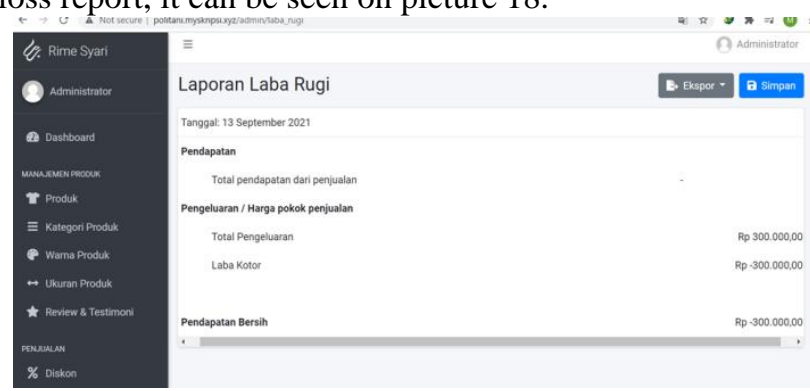

Picture 18. Profit and Loss Data Display

\section{O. Post Data}

This page is a display for adding post data to the Rime Syar'I android application, it can be seen in picture 19 .

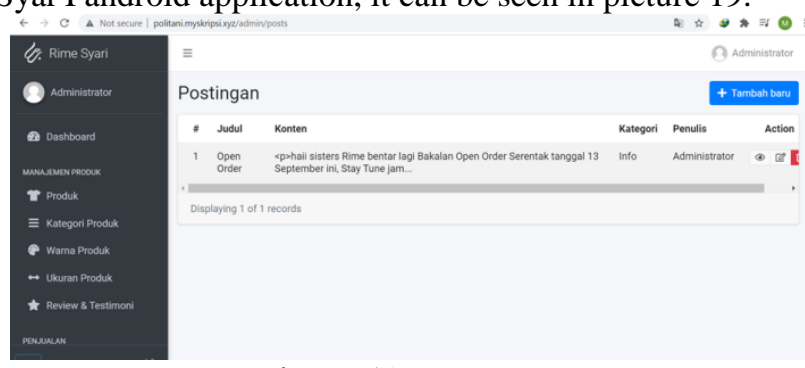

Picture 19. Post Data

\section{P. User Data Display}

This page is a display to display admin, customer, and reseller user data, who are registered in the administration web application and users who register on the Rime Syar'I sales android application, which can be seen in picture 20.

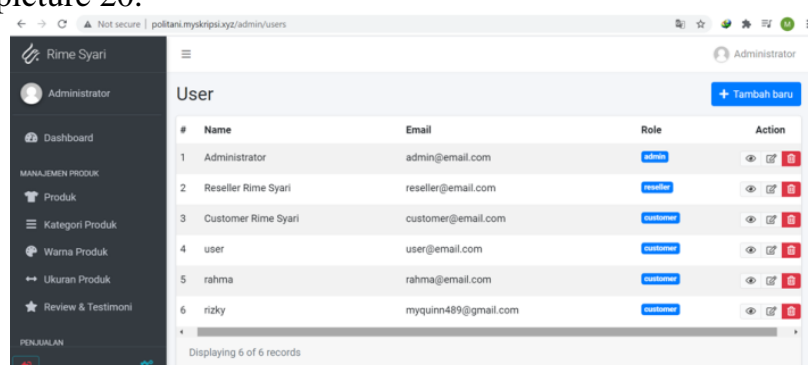

Picture 20. User Data Display

\section{Q. Shipping Address Data Display}

This page is a display for displaying shipping address data, whether it's admin addresses, registered customers, and resellers, it can be seen on picture 21 .

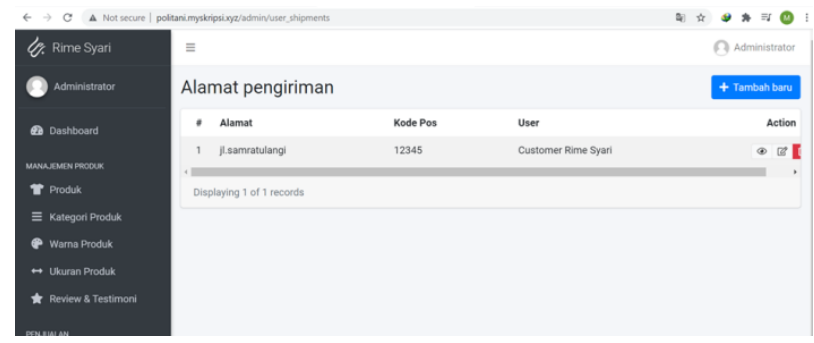


Picture 21. Shipping Address Data Display

\section{R. Display Data File}

This page is a display to display data files that have been uploaded on the web such as product photo files, which can be seen on picture 22 .

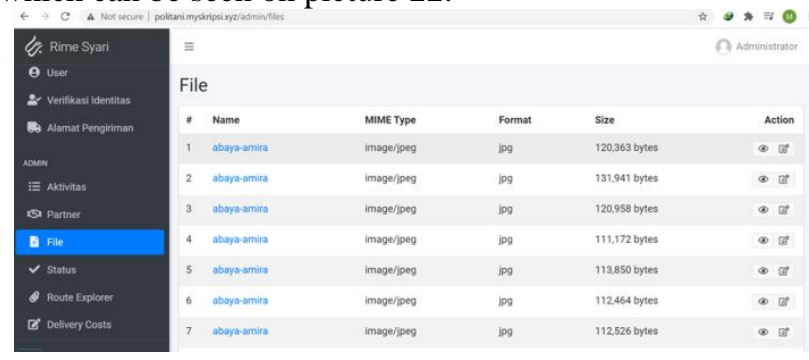

Picture 22. Display Data File

\section{S. Status Data Display}

This page is a display to display the status of shipments that have been ordered, which can be seen in picture 23.

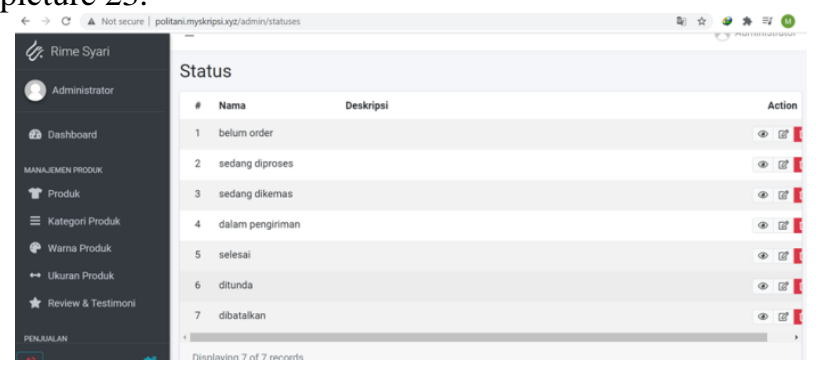

Picture 23. Status Data Display

\section{CONCLUSIONS}

Based on the results of the implementation of the Rime Syar'I administration web application, it can be concluded, This application was designed using the Rapid Application Development method, this administration web application was built to facilitate the administration of Rime Syar'i's business sales which can facilitate Rime Syar'i's business in managing its business, be it sales activities, administration, and business reports.

\section{REFERENCES}

Akbar, A. S. (2017). Rancang Bangun Sistem Informasi Administrasi Hotel Jurnal Disprotek. 8, 26-41.

Alhogbi, B. G. (2017). Sistem Informasi Penjualan Berbasis Web Pada Kedai Kopi Abg. Journal of Chemical Information And Modeling, 53(9), 21-25. Http://Www.Elsevier.Com/Locate/Scp

Fibriyanti, Y. V., Nuryanawati, A. M., \& Alviani, S. (2020). Pembuatan Media Promosi, Sistem Administrasi Dan Manajemen Pemasaran Berbasis Web Pada Mitra Kelompok Usaha Bersama (Kube ) Nelayan Di Desa Kranji Kecamatan Paciran Kabupaten Lamongan. 3(1), 53-57.

Ilmiah, P., Fahrudin, I. N. U. R., Informatika, P. S., Komunikasi, F., Informatika, D. A. N., \&
Surakarta, U. M. (2016). Sistem Informasi Administrasi Service Kendaraan Bermotor Dan Katalog Spare Part Berbasis Web Dengan Teknologi Single Page Application (Spa).

Junirianto, E., \& Kurniadin, N. (2020). Pengembangan Aplikasi Point Of Sale Berbasis Android Menggunakan Metode Rapid Application Development. Jointecs (Journal Of Information Technology And Computer Science), 5(3), 211. Https://Doi.Org/10.31328/Jointecs.V5i3.1564

Kusuma, A. P., \& Prasetya, K. A. (2017). Perancangan Dan Implementasi E-Commerce Untuk Penjualan Baju Online Berbasis Android. Antivirus: Jurnal Ilmiah Teknik Informatika, 11(1), 1-11. Https://Doi.Org/10.35457/Antivirus.V11i1.194

Marliani, L., \& Si, M. (2016). Definisi Administrasi Dalam Berbagai Sudut Pandang. 150, 17-21.

Saleh, A., Pawennari, A., Padhil, A., Industri, J. T., Industri, F. T., Indonesia, U. M., Makassar, K., Penjualan, A., \& Toko, P. (2018). Penjualan Pada Toko Lintang Outdoor. 3(1), 15-20.

Sari, W. E., Junirianto, E., Franz, A., \& Khamidah, I. M. (2021). Video Branding Untuk Promosi Usaha Mikro Kecil Menengah Info Artikel Abstrak Branding Atau Pemasaran Produk Saat Ini Telah Tersedia Dalam Berbagai Bentuk. Selain Dalam Bentuk Tulisan Dan Gambar , Kini Dengan Sehingga Mudah Disebarluaskan Melalui Media So. 4(36), 10-18. Https://Doi.Org/10.33474/Jipemas.V4i1.7174

Syukron, A. (2020). Sistem Informasi Manajemen Administrasi Keuangan Panti Asuhan Berbasis Website. Jurnal Responsif: Riset Sains \& Informatika, 2(2), 150-157. 